the consideration of the Council whether this department of / March 1st, 1887, underwent operation on March 8th, 1887, the Society's rôle might not with advantage be extended. Of the work of those distinguished members who come nearer to our own time I can venture to say little. 'Time is needed to afford the perspective necessary to enable us to appraise their work at its just value. I will not presume to criticise the living. There are two names of men who are deceased, however, which I cannot pass over without a word-viz., those of Dr. Sibson and Mr. James Lane, colleagues and valued friends of my own at St. Mary's Hospital and former Presidents of this Society. Dr. Sibson was the first Harveian lecturer, and gave a series of demonstrations of arterial tension in Bright's disease, a subject then beginning to attract special attention from the observations of Traube; thus developing a line of clinical research which has been most fruitful in results. Mr. James Lane, to whose initiative the Society owes the foundation of the lectureship, delivered the second course, containing valuable practical observations on syphilis. Both have passed away, leaving honoured memories behind them.

\section{NOTES OF THIRTY CASES OF EXCISION OF THE KNEE-JOINT.}

BY A. G. MILLER, F.R.C.S. EDIN.,

LECTURER ON CLINICAL SURGERY AND SENIOR SURGEON TO THE ROYAI INFIRMARY, EDINBURGH.

CASE 1.-D. M- , aged twenty-three. He was admitted to the Edinburgh Royal Infirmary on Oct. 25th, 1884, underwent operation on Jan. 19th, 1885, and was discharged on May 1st, 1885. He suffered from gelatinous synovial membrane and was ill for three or four years. Tnere were suppuration and sinuses. Treatment : Scott's dressing and Thomas's splint for three months during stay in hospital previously to operation. The result was ascertained by letter in November 1892. The leg was not very strong. The patient walked with two sticks and has been free from suppuration and discharge only during the last two years.

CASE 2.-J. B-, aged twenty-five. She was admitted on Dec. 7th, 1885, underwent operation on March 19th, 1886, and was discharged on Nov. 22nd, 1886. Disease: Tubercle of bone of theumatic origin. She was received from Dr. Wyllie's ward, when she was treated for rheumatism of the knee, arms and shoulder. There was no history of injury. The pain persistent in the internal lateral ligament of the knee. Previous treatment: McIntyre splint; soda and carbolic fomentations. She contracted scarlet fever after operation. Two months later the limb was loose, Eight months after operation the limb was firm and useful. The result was ascertained by letter in Nov. 1892. The patient still wears a bandage as support. She can "walk any distance" and do her "work without any trouble."

CASE 3.-J. SJune 4th, 1886, underwent operation on June 7th, 1886, and was discharged on Nov. 18th, 1886. Disease: Gelatinous synovial membrane with suppuration. The result was ascertained by letter in November, 1892. "Quite as strong as the other one."

CASE 4.J. S_- aged seventeen. He was admitted on June 20th, 1886, underwent operation on June 25th, 1886, and was discharged on August 20th, 1886. Disease: Bone and synovial tubercle. Previous treatment : Blisters and posterior splint, and Thomas's splint for several months. 'The result was very good. He is able to run and jump. He was shown to the Edinburgh Medico-Chirurgical Society in May, 1889.

CASE 5.-I. M- aged eighteen. She was admitted on April 7th, 1886, underwent operation on Aug. 12th, 1886, and was discharged on Oct. 29th, 1886. The disease was extensive in the bone and synovial membrane. The limb was amputated for return in cellular tissue on Sept. 23rd, 1886.

CASE 6.-K. B-—, aged eighteen. She was admitted on Aug. 2nd, 1886, underwent operation on Ang. 16th, 1886, and was discharged on Nov. 17th, 1886. Disease: Gelatinous synovial membrane. The result was good; the knee is firm.

CASE 7.-I. B 一, aged twenty-three. He was admitted on Aug. 24th, 1886, underwent operation on Aug. 27th, 1886, and was discharged on Nov. 22nd, 1886. Disease : Synovial tubercle. The result was very good. He was seen in 1891 and walked well; the leg was sound and firm, and there was no complaint.

CASE 8.-M. D_, aged thirteen. She was admitted no and was discharged on May 18th, 1887. Disease: Strumous synovial membrane. She went out with the leg in a plaster case ; the bones were sutured with, wire. The result, was very satisfactory. She was seen in 1890

CAsE 9. - W. (-.-., aged twenty. He was admitted on Sept. 1st, 1887, underwent operation on Sept. 6th, 1887, and was discharged on Dec. 8th, 1887. Disease: Gelatinous synoviar membrane with peri-articular abscess. The general l,calth was bad. Amputation took place on Nov. 10th, 1887, for return f the disease in the bone and soft parts.

Case 10. - G. R-_, aged thirty. He was admitted on Sept. 15th, 1887, underwent operation on Sept. 27 th, 1887, and was discharged on Nov. 30th, 1887. Disease : Gelatinous synovia membrane; ill five years. The result was ascertained by letter in Nov., 1892 ; he was enjoying good health, the leg was quite strong and he was "able to do any sort of work."

CASE 11.-M. F-_, aged twenty-two. She was admitted on June 8th, 1887, underwent operation on Oct. $27 \mathrm{th}, 1887$, and was discharged on Jan. 4th, 1888, with plaster case on, because the knee was too movable. She was readmitted on Jan. 10th. 1890, underwent operation a second time on March 7 th, 1890, and was discharged May 2nd, 1890 (two drills were employed). Disease: Gelatinous synovial membrane. She was ill eight years. Previous treatment: Scott's dressing and posterior splint. The second operation for movable joint was undertaken at the patient's urgent request. 'The result, was ascertained by letter in November, 1892. The leg was strong and she " can walk any distance," and "does not fee] in the least pained or fatigued."

CAsE 12.-J. M--, aged forty-two. He was almitted or Feb. 18th, 1888, underwent operation on Feb. 21st, 1888 and was discharged on Jan. 19th, 1889. Thedisease was tuberculous and extensive; the history was of rheumatic origin: the bones were stitched with strong catgut. He died in Glasgow Poorhouse of phthisis in December, 1891. The leg was fairly useful to the last. The patient was very intemperate.

CASE 13.-J. C--, aged eleven. She was rimitted on April 16th, 1888, underwent operation on April 20th, 1888, and was discharged on May 17th, 1888. Disease:-Synovial tubercle. She was ill three months. The result was satisfactory. The limb is firm. (See engraving from photograph taken at time of discharge in May, 1888.)

CASE 14.-J. M-, aged twelve. She was admitted on June 18th, 1888, underwent operation on June 22nd, 1888 and was discharged on July 28 th, 1888 . The result was ascer tained by letter in November, 1892 . She was in good health the "leg as strong as ever," and she was "quite able for work."

CAsE 15.-D. S-, aged seven. He was admitted on June 25th, 1888, underwent operation (erasion) on June 26th, 1888, and was discharged on Sept. 1st, 1888. Disease : Strumours synovial membrane. Result : Knee quite firm, slightly flexed, and he walks easily. This was ascertained in June, 1890 when he was readmitted for slight injury to the same limb.

CASE 16.-Mrs. C——, aged thirty. She was admitted or. Dec. 5th, 1888, underwent operation on Dec. 11th, 1888, and was discharged on Feb. 6th, 1889. She was ill five months Disease: Synovial tubercle. Previous treatment: Blisters ane Scott's dressing with splint. The result was ascertained by letter in November, 1892. Her health was good, there was no pain in the leg and no trouble from it. When seen in 1891 the result was considered very satisfactory.

CASE 17._J. L__, aged nineteen. He was admitted on Feb. 7th, 1889, underwent operation on Feb. 19th, 1889, and was discharged on June 19th, 1889. Disease : Advanced tuberculosis. He was ill one year. Amputation was performe on May 21st, 1889 , for return of disease in the soit parts.

CASE 18.-W. B- aged nineteen. He was admittel on Feb. 20th, 1889, underwent operation on Feb. 26th, 1889 and was discharged on April 4th, 1889. Disease: Ankylosis after partial dislocation backwards and fracture of externa] condyle, with commencing tuberculous clisease. Four years had elapsed after the injury and two years since the pain and swelling commenced. There was a caseated spot in the head of the tibia and the gelatinous synovial membrane. The result was ascertained by letter in November, 1892. 'The leg was quite strong and useful. (See engraving from photograph taken at the time of discharge in 1889.)

CASE 19.-G. P-, aged twelve. He was admitted on June 19th, 1889, underwent operation on June 25th, 1889 , and was discharged on Dec. 30th, 1889, with sinuses. Amputa tion took place on May 29th, 1891. There was advances 
strumous disease as well as recurrence in the bone and cellular tissue.

CASE 20.-R. T—, aged fifty-seven. He was admitted on April 30th, 1889, was readmitted on July 26th, 1889, underwent operation on Aug. 1st, 1889, and was discharged on Sept. 28th, 1889. The disease was syphilitic. Previous treatment:

Case 13.

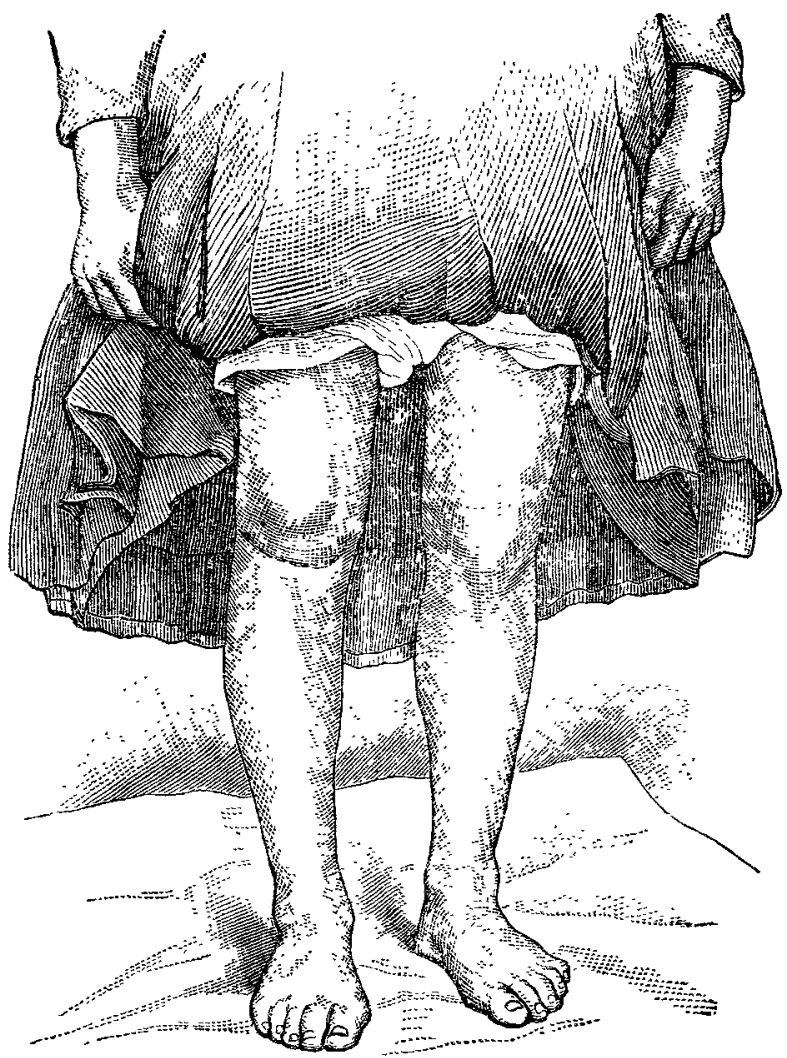

CASE 18.

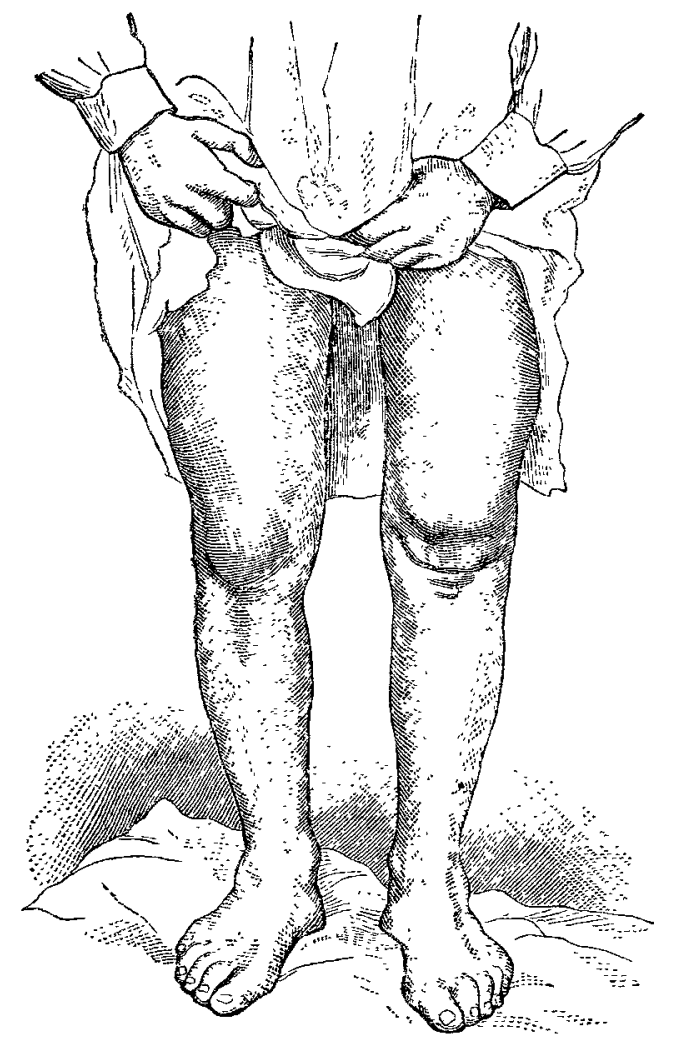

Scott's dressing and plaster case. The result was ascertained by letter in November, 1892. The leg was "sound and well, there was no pain," he was very strong, and "could walk three miles in an hour, so is very useful."

CASE 21. J. D-, aged twenty-one. He was admitted on July 31 st, 1889, underwent operation on Aug. 9th, 1889, and was discharged on Sept. 26th, 1889. The disease was strumous and of old standing, and was cured with ankylosis and flexion. The result was seen in May, 1892, when it proved an excellent, useful limb, and he walks well, with slight motion.

CASE 22. - E. S—, aged twenty-two. She was admitted Nov. 7th, 1889, underwent operation on Nov. 12th, 1889, and

CASE 23.

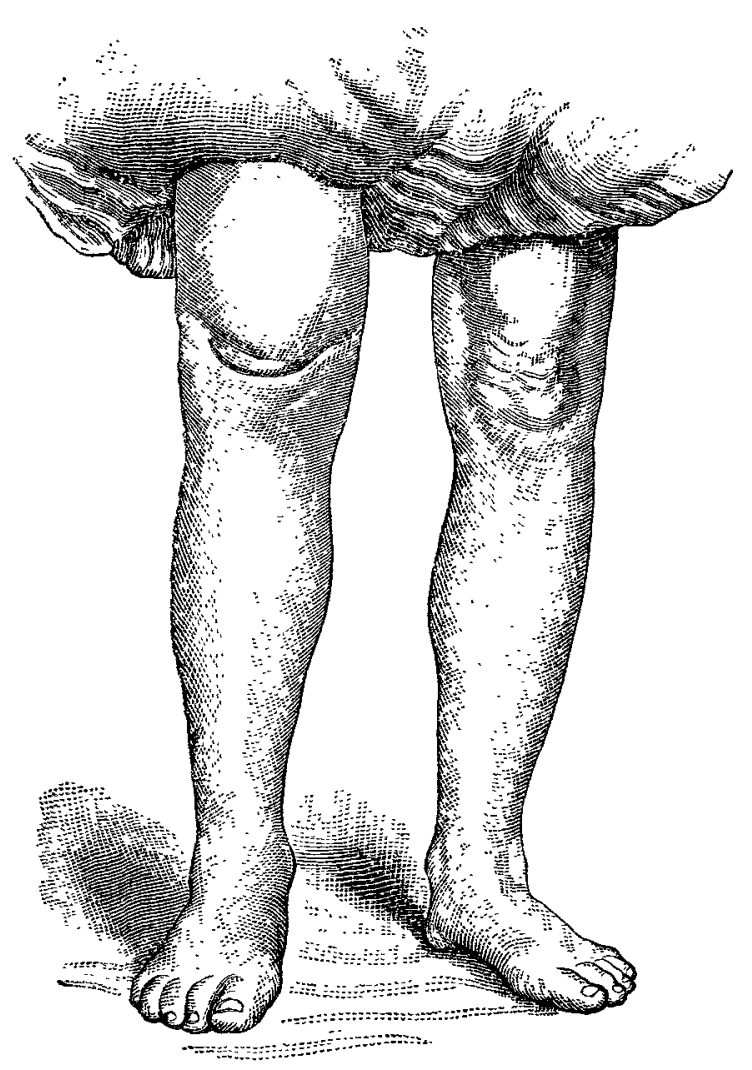

CASE 26.

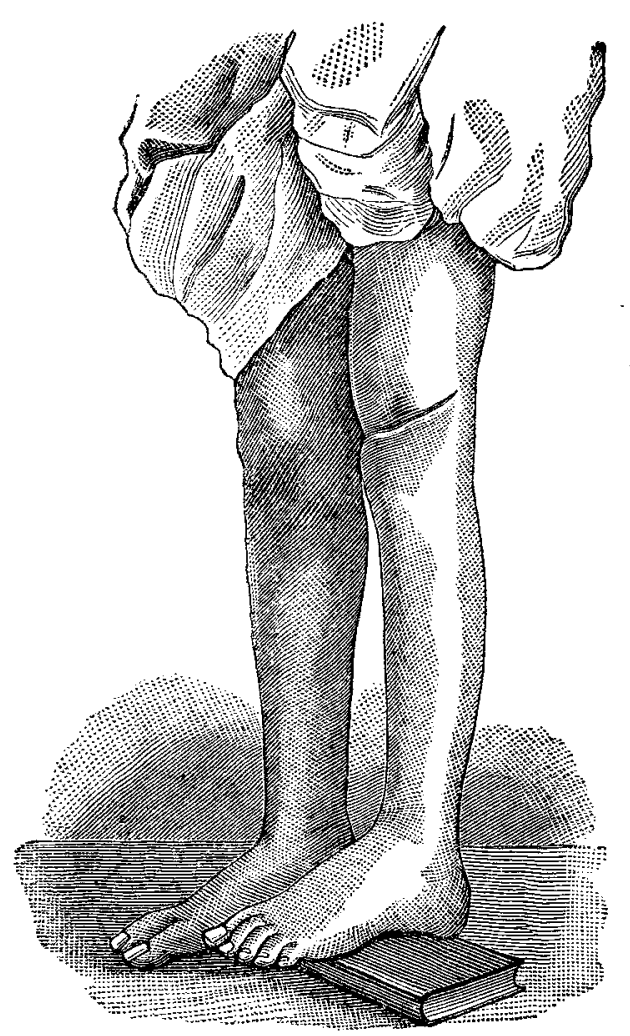

was discharged on March 5th, 1890. There was strumous disease after operation for genu valgum (Chiene's) four years previously. Ankylosis was tried. Result : She was seen in August, 1892 ; she walks fairly well, without either crutch or stick, and the limb is quite firm. The other limb was operated on for genu valgum in 1885 . 
CASE 23.-Mrs. L- - aged thirty. She was admitted on / Sept. 25th, 1891, underwent operation on Oct. 16th, and was Dec. 12th, 1889, underwent operation on Dec. 19th, 1889, and discharged on Jan. 20th, 1892. Drills were employed. She was discharged on Feb. 12th, 1890. There was strumous was readmitted on March 10th, 1892, with a sinus along the disease after rheumatism. She was ill eight years. Result : track of the drill. The leg was healerl in May. Result: She When seen in October, 1892, the knee was firm and was seen in November, 1892; the leg was firm and soundly slightly flexed; she walked with only a slight limp and did healed. The child walks well, with only a slight limp. housework regularly.

CASE 24. - M. T- aged sixteen. She was admitted on Dec. 21st, 1889, underwent operation on May 2nd, 1890, and was discharged on July 29th, 1890. Disease strumous. She was ill for one year. Drills were used. Previous treatment: Scott's dressing and Thomas's splint. She returned in February, 1891, with sinus, which was scraped and healed up in four weeks. The result was very satisfactory and was shown to the Edinburgh Medico-Chirurgical Society in Norember, 1892.

CASE 25. - Mrs. F__ aged forty-three. She was admitted

CAsE 28. - Mrs. I - , aged thirty-seven. She was admitted on Oct. 26th, 1891. Underwent operation on the 30th, and was discharged on Jan. 23rd, 1892. Drills were employed. Result : Sinuses ; limb no use ; amputation advised.

CASE 29.-W. M- aged eight. He was admitted on Jan. 25th, 1892, underwent operation on the 29th, and was discharged on April 23ril. Drills were employed. Disease : Synovial tubercle. Result: The leg was firm and useful, and he was able to run about, go to school \&c. There was hardly any limp with a high heel. He was seen Jan. 11th, 1893.

Table of Thirty Cases of Excision of the Knet.

\begin{tabular}{|c|c|c|c|c|c|c|c|}
\hline Case. & $\begin{array}{l}\text { Initials of } \\
\text { name. }\end{array}$ & Age. & Leg. & $\begin{array}{l}\text { Date nf opera- } \\
\text { tion. }\end{array}$ & Disease. & Result. & $\begin{array}{l}\text { When last seen or } \\
\text { heard from. }\end{array}$ \\
\hline 1 & D. M. & 23 & Right & Jan. 19, 1885. & $\begin{array}{c}\text { Synovial tubercle; sinuses } \\
\text { septic }\end{array}$ & Fairly gnod; no pain; walks & Letter 1892. \\
\hline 2 & J. B. & 25 & Right & Narch 19,1886 & $\begin{array}{c}\text { Rheumatic synovitis followed } \\
\text { by bone tubercle. }\end{array}$ & Very good. & Letter Nov., 1892. \\
\hline $\begin{array}{l}3 \\
\vdots\end{array}$ & $\begin{array}{l}\text { J. S. } \\
\text { J. S. }\end{array}$ & $\begin{array}{l}26 \\
17\end{array}$ & $\begin{array}{l}\text { Right } \\
\text { Right }\end{array}$ & $\begin{array}{l}\text { June } 7,1886 . \\
\text { June } 25,1886 .\end{array}$ & $\begin{array}{l}\text { Advanced synovial tubercle. } \\
\text { Advanceu bone and synovial } \\
\text { tubercle. }\end{array}$ & $\begin{array}{l}\text { Very gond. } \\
\text { Very good. }\end{array}$ & $\begin{array}{l}\text { Letter Nov., } 1892 . \\
\text { Shown to Med .Chir. Soc. } \\
\text { May, } 1889 .\end{array}$ \\
\hline 5 & I. M. & 18 & - & Aug. 12, 1886. & Extensive tuberculous disease. & $\begin{array}{l}\text { Amputation Sept. } 23 r d, 1886, \text { for } \\
\text { return of tubercle in cellular } \\
\text { tissue. }\end{array}$ & \\
\hline $\begin{array}{l}8 \\
7\end{array}$ & $\begin{array}{l}\text { K. B. } \\
\text { I. B. }\end{array}$ & $\begin{array}{l}18 \\
23\end{array}$ & - & $\begin{array}{l}\text { Aug. } 16,1886 . \\
\text { Aug. } 47,1886 .\end{array}$ & $\begin{array}{l}\text { Synovial tubercle. } \\
\text { Synovial tubercle. }\end{array}$ & $\begin{array}{l}\text { Good. } \\
\text { very grod. }\end{array}$ & Seen 1801. \\
\hline 8 & M. D. & $\begin{array}{l}13 \\
24\end{array}$ & $\overline{\text { Right }}$ & $\begin{array}{l}\text { March } 8,1887 . \\
\text { Sept. } 6,1887 .\end{array}$ & $\begin{array}{c}\text { Synovial tubercle } \\
\end{array}$ & Very gond. & Seen 1890 . \\
\hline$y$ & & & KIIgnt & sepu. 0,1000 & Extensive tuberculous aisease. & $\begin{array}{l}\text { Amputation Nov. 10th, 1887, for } \\
\text { roturn of tubercle in bone } \\
\text { and cellular tiscue. }\end{array}$ & \\
\hline $\begin{array}{l}10 \\
11\end{array}$ & $\begin{array}{l}\text { G. R. } \\
\text { M. F. }\end{array}$ & $\begin{array}{l}30 \\
22\end{array}$ & $\begin{array}{l}\text { Right } \\
\text { Lett }\end{array}$ & $\begin{array}{l}\text { Sept. } 27,1887 . \\
\text { Oct. } 27,1887 \text {. }\end{array}$ & $\begin{array}{l}\text { Synovial tubercle. } \\
\text { Synovial tubercle. }\end{array}$ & $\begin{array}{l}\text { Very good. } \\
\text { Limb too movable. }\end{array}$ & Letter Nov., 1892. \\
\hline 12 & $\begin{array}{c}\text { (2nd operation) } \\
\text { J. M. }\end{array}$ & $\overline{42}$ & Right & $\begin{array}{l}\text { March 7, } 1890 . \\
\text { Feb. 21, } 1888 .\end{array}$ & $\begin{array}{c}\text { Extensive tuberculous disease } \\
\text { of rheumatic or gin. }\end{array}$ & $\begin{array}{l}\text { Very good. } \\
\text { Fair. }\end{array}$ & $\begin{array}{l}\text { Letter Nov., } 1892 . \\
\text { Died of phthisis } \\
\text { Dec., } 1891 .\end{array}$ \\
\hline 13 & J.C. & $\begin{array}{l}11 \\
12\end{array}$ & $\begin{array}{l}\text { Right } \\
\text { Right }\end{array}$ & $\begin{array}{l}\text { April } 20,188 \AA \\
\text { June } 22,1888\end{array}$ & $\begin{array}{l}\text { Synovial tubercle. } \\
\text { Synovial tubercle }\end{array}$ & Good. (See engraving) & Ietter $\overline{\text { Noy }}, 1892$ \\
\hline 35 & D. S. & 7 & left & June 26,1888 . & Synovial tubercle (erasion). & Very good. & Seen 1890 \\
\hline $\begin{array}{l}16 \\
17\end{array}$ & Mrs. C. & $\begin{array}{l}30 \\
19\end{array}$ & $\begin{array}{l}\text { Right } \\
\text { R'ght }\end{array}$ & $\begin{array}{l}\text { Dec. } 11,1888 \\
\text { Feb. } 19,1889 .\end{array}$ & $\begin{array}{l}\text { Synovial tubercle. } \\
\text { Extensive tuberculous disease. }\end{array}$ & $\begin{array}{l}\text { Very good. } \\
\text { Amputation Miay } 21 \text { st, } 1878 \text {, for }\end{array}$ & Seen 1891. Letter 1892 . \\
\hline 18 & W. B. & 19 & Left & Feb. 26, 1839. & $\begin{array}{l}\text { Ankylosis after partial disloca. } \\
\text { tion; tubercle in tibia. }\end{array}$ & $\begin{array}{l}\text { return in cellular tissue. } \\
\text { ve y good. (See engraving.) }\end{array}$ & Letter 1892 \\
\hline 19 & G. $P$. & 12 & Left & June 25, 1889. & Extensive tuberculous disease. & $\begin{array}{c}\text { Amputation May 29th, 1891, for } \\
\text { return in bone and cellular } \\
\text { tissue. }\end{array}$ & $\ldots$ \\
\hline $\begin{array}{l}20 \\
81\end{array}$ & $\begin{array}{l}\text { R. T. } \\
\text { J. D. }\end{array}$ & $\begin{array}{l}57 \\
21\end{array}$ & $\begin{array}{l}\text { Left } \\
\text { L ft }\end{array}$ & $\begin{array}{l}\text { Ang. } 1,1889 . \\
\text { Auy. } 9,1889 .\end{array}$ & $\begin{array}{l}\text { Syphilitic ostitis. } \\
\text { Ankylosis after long-standing } \\
\text { tuberculous disease healed. }\end{array}$ & $\begin{array}{l}\text { Very good. } \\
\text { Very good ; shight motion. }\end{array}$ & $\begin{array}{c}\text { Letter } 1898 \\
\text { Seen May, } 189\end{array}$ \\
\hline 92 & I. T. & 22 & Right & Nov. 12, 1889. & $\begin{array}{l}\text { Ankylosis after operation for } \\
\text { genu valgum; tubercle dis- } \\
\text { covered at }\end{array}$ & Fairly good. & Seen Aug., 1892. \\
\hline 23 & Mrs. L. & 30 & Right & Dec. $19,1889$. & $\begin{array}{c}\text { covered at operation. } \\
\text { Bone tubercle secondary to } \\
\text { iheumatism. }\end{array}$ & Very good. (See engraving.) & Seen 1892. \\
\hline 21 & M. T. & 16 & Right & May 2, 1890 & Synovial and bone tubercle. & Very good. & $\begin{array}{l}\text { Shown to Med.-Chir. } \\
\text { Soc. } 1892 \text {. }\end{array}$ \\
\hline 25 & Mrs. F. & $48(?)$ & Right & Niay 20,1890 . & $\begin{array}{l}\text { Tubercle, extensive and acute, } \\
\text { after rheumatoid arthritis. }\end{array}$ & $\begin{array}{c}\text { Died May } 24 \text { th, } 1890, \text { from fatty } \\
\text { heart and persistent chloro- } \\
\text { form sickness. }\end{array}$ & \\
\hline 26 & L A. & 15 & Left & Oct. 21,1890 . & Synovial tubercle. & Very good. (See engraving.) & Letter Nov., 1892.. \\
\hline 27 & A. W. & 10 & Left & Oct. 10,1891 . & Synovial and bone tubercle. & $\begin{array}{l}\text { Return of tubercle in femur } \\
\text { along line of drill; nltimate } \\
\text { result good. }\end{array}$ & Seen Nov., 1892 \\
\hline 28 & Mrs. I. & 37 & Left & Oct. 30,1891 . & Extensive tuberculous disease. & $\begin{array}{c}\text { Discharged with sinus Jan., } 1892 \\
\text { anputation ad vised. }\end{array}$ & \\
\hline $\begin{array}{l}29 \\
30\end{array}$ & $\begin{array}{l}\text { W. M. } \\
\text { W. ע. }\end{array}$ & $\begin{array}{l}8 \\
5 \\
5\end{array}$ & $\begin{array}{l}\text { Left } \\
\text { Ieft }\end{array}$ & $\begin{array}{l}\text { Jan. } 29,1892 . \\
\text { Mlay } 28,1892 .\end{array}$ & $\begin{array}{l}\text { Synovial tubercle. } \\
\text { Synovial and bone tubercle. }\end{array}$ & $\begin{array}{l}\text { Very good. } \\
\text { Very good. }\end{array}$ & $\begin{array}{l}\text { Seen Jan., } 189 \% . \\
\text { Seen Nov., } 1892 .\end{array}$ \\
\hline
\end{tabular}

on May 9th, 1890, underwent operation on May 20th, 1890, and died on May 24th, 1890, from fatty heart and persistent chloroform sickness. The disease was strumous, after chronic rheumatoid arthritis. The necropsy showed fatty degeneration of the muscular substance of the heart. The liver and kidneys were both very fatty. The brain showed sub-arachnoid effusion. The wound was healthy and sweet, apparently nearly healed.

CASE 26.-L. A — aged fifteen. She was admitted on Sept. 5th, 1890, underwent operation on Oct. 21st, 1890, and was dismissed on Dec. 30th, 1890, with plaster case on. Disease : Synovial tubercle. Drills were employed. The result (by letter) was communicated by her father in November, 1892. "Walks five miles to her work daily; can run, jump and skip about as if nothing had been wrong."

CASE 27.-A. W - aged ten. She was admitted on on May 28th, underwent operation on June 24th, and was discharged on Aug. 5th, with the limb in plaster. Disease: Synovial and bone tubercle, with abscess in the head of tibia. One drill was inserted. Previous treatment: Scott's dressing and Thomas's splint. The wound healed with only two dressings. The result was seen in November, 1892. The limb was quite firm and useful. The patient walks and runs about with a very slight limp.

$$
\text { Analysis of the Table. }
$$

1. There were two deaths. One (No. 12) took place three years and ten months after the operation and was therefore not properly attributable to it. The other (No. 25) occurred from fatty heart and chloroform sickness four days after the operiation.

2. Four cases of amputation for return of disease (Nos. 5, 
9, 17 and 19). N.B.-No. 28 should be added, for disease still ezists and amputation ought to be performed. In all these cascs excision was performed under protest (as it were), amputation having been alvised from the first. Amputation was recommended also in Cases 12 and 25, both of whom died.

3. Tho oldest patient was aged fifty-seven, the youngest five yexrs. The average age was about twenty-two years.

4. The right leg was the one operated on in fifteen cases, the left in eleven. In the remaining five cases the side is not mentional.

5. ${ }^{r} i l e$ disease on account of which excision was performed was tuberculous in all but one, which was syphilitic (No. 20). In three cases (Nos. 2, 12 and 23) the tubercle was secondary to rheumatism, and in one (No. 25) to rheumatoid arthritis. Injury (dislocation) (No. 18), and an operation (No. 22) for genv. valgum), were the apparent exciting causes in two caser. after an interval of four years in each. In thirteen cases the tubercle was apparently confined to the synovial membrano. In three cases bone tubercle alone existed, whilst in twe Tre all the tissues were affected.

6. I can speak decidedly of the result in twentyeight of the cases which were seen or heard from at period: varying from one to seven years after operation. T'wo bave died; four have undergone the operation of amputation, and one more ought to be amputated. In three cases the resulting limbs have been fairly useful and in the remaining eighteen cases the results have been very satisfactory to the patient as well as to the surgeon. This, however, includes one case of erasion. Of the thirteen synovial cases ten had a very good result. Of the three bone tubercle cases all were very good; whilst of the twelve more advanced cases only three gave very good results, two were marked "good," four were amputated, one ought to have been rmplisted and two died. Of the two cases that have not been lieard from or seen lately, one was operated on a year ago, rith good results, and the other is believed to have had fairly sood results whose limb is depicted in the engraving No. 13

7. The engravings (Nos. 13, 18, 23 and 26) are from photograph taken mostly when the patients left the hospital. They tro not specially selected cases.

I present these cases to the profession as an illustration of what may be done to conserve useful limbs by means of an operation which fifty years ago was not looked upon with much favour. I claim that the results are as good as are likely to be obtained by any similar operation. My method of operation is described by me at length in a paper which appeared in the Edinburgh Medical Journal for July, 1889, and again in the number for December, 1892. The main featur $=$ of this method I set before me when I began to operatic in 1885 . The exact steps of the operation which my experience of these thirty cases has led me to adopt I have given, 4 iready stated. Since making up the foregoing table I bave operated twice, and both of the patients have left the horpita, with firm and apparently useful limbs. Without giving datails unnecessarily I may say that I aim at removing the anterior (and principal) portion of the diseased synovial membrane lyy reflecting the skin off it and dissecting it out as if it were: tumour (and a tuberculous tumour it certainly is). I scrape awsy (this being the longest part of the operation) the remaining synovial membrane before cutting the fibrous structures $w$ hich they cover. I always remove slices of bone from the femm and tibia, because I have frequently found unsuspected tuberculous foci after opening up the cancellous dextu' of the epiphyses. A less important part of my procerlu. a (wstretic mainly) is the removal of a portion of skin from the enterior flap so as to do away with the redundancy of skin, so perceptible in the earlier operations which I remember havirg son. Perhaps I may be permitted, in conclusion, to remark that it is not my usual practice to excise strumous knees. I successfully treat them generally (even in hospital patieut(s) by rest, counter-irritation, and immobilisation.

Coatar-crescent, Edinburgh.

Worchister Ophthalmic Hospital. - The annuel report of this institution, read at the yearly meeting of tho sulscribers held a few days ago, had nothing of a sensational character to relate. The progress of the institution bad not been rapid, but its work is much appreciated by the inbabitants of Worcester. One item of information afforded ky the secretary was the satisfactory announcement that in no one year had the receipts reached so large a sum.

\section{STRANGE INCIDENTS IN PRACTICE.}

By Sir WILLIAM B.-DALBY, F.R.C.S. ENG., M.B. CANTAB, CONSULTING AURAL SURGEON TO ST. GEORGE'S HOSPITAL.

I USE the word "strange" in the sense that many of the incidents presently referred to cannot be accounted for, so far as I know, by any course of cause and effect with which the profession can be said to be atall accurately familiar. Nodoubt in the memories of many physicians incidents have happened in regard to which they have often pondered and wondered without being able to arrive at any definite or decided es. planation; and could it be obtained, an account of some of their experiences would be profoundly interesting, not only from a medical, but also from a literary, point of view. Be this as it may, perhaps the very last place from which interesting occurrences might be expected would be from the practice of an aural surgeon, and yet this is not so entirely barren of unexplainable incidents as might be supposed.

It is common enough to hear it said of So-and-so, "It was a terrible shock to him, he has never been the same man since," and this can be readily understood; but it is often not easy to duly appreciate how shock caused by emotion and not by violence acts, except on the mind. The effects of shock are assuredly not always confined to the mind, since it has been known to cause instant death, not to mention various degrees of collapse. All this part of the subject, so far as it relates to bodily effects, is graphically and charmingly dealt with in Sir W. Savory's article on Collapse in "Holmes' System of Surgery," but I wish now to draw attention to the effects of emotion on the special senses. Some years ago a lady was standing before her toilet table, and looking through an open door into her husband's dressing.room saw in a mirror the reflection of her husband in the act of cutting his throat. From that moment she was absolutely deaf to all sound. A similarly sudden and complete loss of hearing some years later happened to a young married lady who was suddenly brought face to face with her dead husband whom she believed to be quite well, and whom she was going to meet after a long absence. I have on various occasions alluded to the remarkable effects which are produced upon the hearing by emotional influences, not only by great mental shocks but by mental strain, strain which is sometimes of a prolonged character, whilst at other times the period of strain only extends over a few minutes, such as is produced by bad news unexpectedly given, or news which entails calamity on the individual or some one dear to him. Not only sudden grief, but also overwhelming joy I have known to instantly make its recipient quite deaf; in short, any very powerful emotional influence is capable of producing this effect. This cessation of the functions of nerrous matter which includes the special sense of hearing is, to say the least, very remarkable. It is but a poor and lame explanation to ascribe it to what is termed "shock." At what points does the shock act? Certainly not as in the constitutional effects of shock upon the heart and mind. What portion of the brain is affected, and in what manner? Here, then, are grounds for speculation. The fact of the hearing being lost on both sides places the locale of the lesion very deep, and one is led to think of the medulla. It is in the highest degree probable that postmortem appearances would not reveal anything, for this has been shown to be the case in examples of furious tinnitus with loss of hearing on one side. It would seem that the sense of hearing hang's (to speak metaphorically) by a thread very slender when compared to the sense of sight, and in this way bears a strong resemblance to the sense of smell, which on several occasions I have known to be lost by very strong: emotional influence; and not only to be lost, but to become disordered, and so acting on the sense of taste as to produce curiously unpleasant results. Thus, a gentleman who was quite remarkable for his highly sensitive and accurate taste in the matter of wine, and upon whose opinion vintages were bought. lost his sense of smell and with this, of course, his sense of taste, but with this addition, - viz., that the sense, besides being lost, became disordered in an unnatural manner, so that what he ate and drank left behind it a horrible musty odour, which he described as resembling the faint odour of a corpse. The health, both bodily and mentally, of this man was excellent, and the change to which 